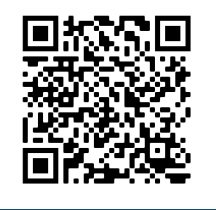

Keywords:

Agricultural emissions

Lichen communities

Livestock farming

Nitrophytic

Historic:

Received 02/ 03/2020

Accepted 04/06/2020

+Correspondence: edithflippini@gmail.com
Edith Filippini ${ }^{1 \mathrm{a}, 2}+$, Juan Manuel Rodríguez ${ }^{1 \mathrm{~b}, 2}$, Gonzalo Quiroga ${ }^{2 \mathrm{a}}$, Cecilia Estrabou ${ }^{1,2}$

\section{DIFFERENTIAL RESPONSE OF EPIPHYTIC LICHEN TAXA TO AGRICULTURAL LAND USE IN A FRAGMENTED FOREST IN CENTRAL ARGENTINA}

FILIPPINI, E.; RODRÍGUEZ, J. M.; QUIROGA, G.; ESTRABOU, C. Differential response of epiphytic lichen taxa to agricultural land use in a fragmented forest in Central Argentina. CERNE, v. 26, n. 2, p.272-278, 2020.

\section{HIGHLIGHTS}

The frequency of lichen families and genera around forest patches changes with land use.

Physciaceae and Collemataceae increased with crop production and native forest area.

Physcia increased in relation to grazing and decreased with stock farming.

The absence of $\mathrm{N}$-emission data could be compensated by these lichens indicators.

\section{ABSTRACT}

The seasonally dry subtropical forest, especially the Espinal forest in central Argentina (one of the most fragmented ecoregions), is affected by intensive agricultural activity. These activities are the main anthropogenic sources of atmospheric nitrogen compounds and their effects on lichens have been extensively studied, making them excellent ecological indicators. However, in the Espinal forest, the agricultural emissions are not monitored therefore analysis of the response of lichen diversity to these activities has a fundamental role in providing baseline data for monitoring. We analyzed changes in the frequency of families and genera of epiphytic lichen communities in 39 circular buffer areas at different scales comprising crop production, stock farming (feedlots), grazing and forest. Significant correlations at different taxonomic levels were detected in relation to land use. Frequency of Physciaceae increased with an increasing area of cropland to a distance of $600 \mathrm{~m}$. Likewise a positive correlation was observed between the frequency of Collemataceae and the forest area. At genus level, Physcia presented a different response to livestock according to the intensity of production, since the frequency of these species increased in forest patches surrounded by grazing but decreased in areas with livestock farming where the stocking density is higher. This result could indicate an eutrophication process in the Espinal ecosystem, even for Physcia species. Our results can be used to start a list of indicator species to impact of agricultural in forest ecosystems. 


\section{INTRODUCTION}

The conversion of natural ecosystems to agricultural land causes the loss, fragmentation or degradation of the habitats available for many species and, therefore, it is one of the major threats to biodiversity worldwide. In Argentina, seasonally dry subtropical forest, especially the Espinal is affected by land use/land cover changes as it is distributed as a semicircle around the Pampas, which in turn is the most transformed ecoregion (Guida Johnson and Zuleta, 20/3). These forests are scarce remnants largely endangered by crop and livestock activities (Cabido et al., 20 I8b).

In addition to the loss of habitat, agricultural activities, mainly intensive farming with fertilizers and intensive animal husbandry, have a great impact on the atmosphere (Fao, 2006). These activities are the main anthropogenic sources of atmospheric nitrogen compounds (Galloway et al., 2003) and their effects on terrestrial vegetation and lichens has been widely reported (Aguillaume et al., 2017; Boltersdorf and Werner, 2014; Frati et al., 2008, 2007; Krupa, 2003; Paoli et al., 2010).

In several European and North American countries, many species of lichens were classified as nitrophytic or oligotrophic according to their response to eutrophication (Geiser et al., 2010; McMurray et al., 2015; Nimis and Martellos, 2017; Pinho et al., 2009). In South America, however, no studies have classified lichen species according to their $\mathrm{N}$-tolerance.

The Espinal ecoregion comprises some of the most suitable soils for agriculture and livestock grazing in the world (Blum, 20I3). In consequence, grain production (mainly soybean, corn, wheat and sunflower) and cattle and pig farming the main economic activity (Viglizzo et al., 20II). Despite this, emissions from these activities are not monitored, so little is known about the effects on lichen diversity (Estrabou et al., 20I I; Filippini et al., 20I4).

Taking into account that the particles/pollutants emitted by agriculture act at the local spatial scale (Pinho et al., 2008), we applied a neighborhood land cover approach to explore the lichen community changes, in particular, searching for taxa that are susceptible to different agricultural activities. The objective of this study was to identify changes in the frequency of families and genera of the lichen community in response to land use in agricultural landscapes with a few remnant patches of Espinal forest from central Argentina.

\section{MATERIALS AND METHODS}

\section{Study area}

The study was conducted in the Espinal ecoregion, central Argentina between 2015 and 2016 (Figure I).
An area of approximately $13,000 \mathrm{~km} 2$ located between $33^{\circ} 8^{\prime} 4 I^{\prime \prime S}-64^{\circ} 25^{\prime} 7 I^{\prime \prime} W$ and $32^{\circ} 24^{\prime} 42^{\prime \prime} S-62^{\circ} 3^{\prime} 7^{\prime \prime} W$ was selected in the central-southern region of the Espinal, where climate, altitude and forest physiognomy conditions were similar. Mean temperature in the study area was $23^{\circ} \mathrm{C}$ in summer and $8^{\circ} \mathrm{C}$ in winter, and the annual precipitation for a 20-year period (198I-20I0) was $800 \mathrm{~mm}$ (Servicio Meteorológico Nacional de Argentina, 2017). The Espinal belong to the southamerican seasonally dry forest. Originally, it was a lowland subtropical forest largely forested; at present, however, it is a landscape of small forest patches dominated by Celtis ehrenbergiana and Prosopis spp., surrounded by land used for crop and livestock production (Cabido et al., 2018; Lewis et al., 2009; Zeballos et al., 2020). The main activities are grain production followed by extensive (cattle grazing) and intensive (feedlot) livestock farming, to a lesser degree.

\section{Sampling design and lichen survey}

Five forest patches (between 50 and 300 ha in area) surrounded by crop fields, grazed pastures and/or feedlots and other livestock rearing units were evaluated within the study area. A total of 39 random sites were surveyed (all sites in the forest); a $20 \mathrm{~m}$ long strip of forest around each patch and adjacent to any of the land use types was not included to avoid the edge effect (Belinchon et al., 2007; Boudreault et al., 2008). We used species accumulation curves to establish the sampling effort on each forest patch.

At each site, a $100 \mathrm{~m}$ transect was established parallel to the adjacent land use; in each transect, 10 phorophytes of $\mathrm{C}$. erhenbergiana or Prosopis spp. were selected (DBH 20-80 cm and bole inclination lower than $20^{\circ}$ ). The effect of light in terms of the different canopy covers was controlled through measurements with a spherical convex densitometer (Jennings et al., 1999). In the field we determined that at canopy cover values similar to or higher than $60 \%$ there is no correlation between light and lichen variables in the study area. For each phorophyte, a grid $(0.2 \mathrm{~m} \times 0.2 \mathrm{~m})$ subdivided into 100 cells was placed $1.5 \mathrm{~m}$ above the ground to identify lichen species and frequency. The grid was placed on the southwest side of the trunk since numerous studies in the region report that it is possible to capture the maximum diversity of epiphytic lichens there (Estrabou 1998; Estrabou et al., 201 I; 2014; Filippini et al., 20।4; Quiroga et al., 2008; Rodriguez et al., 2009). Lichen species were identified using routine techniques in the field and laboratory (Aptroot et al., 20I4; Elix, 20I4; Estrabou et al., 2006; Filippini et al., 2015; Jungbluth et al., 20I I). The 

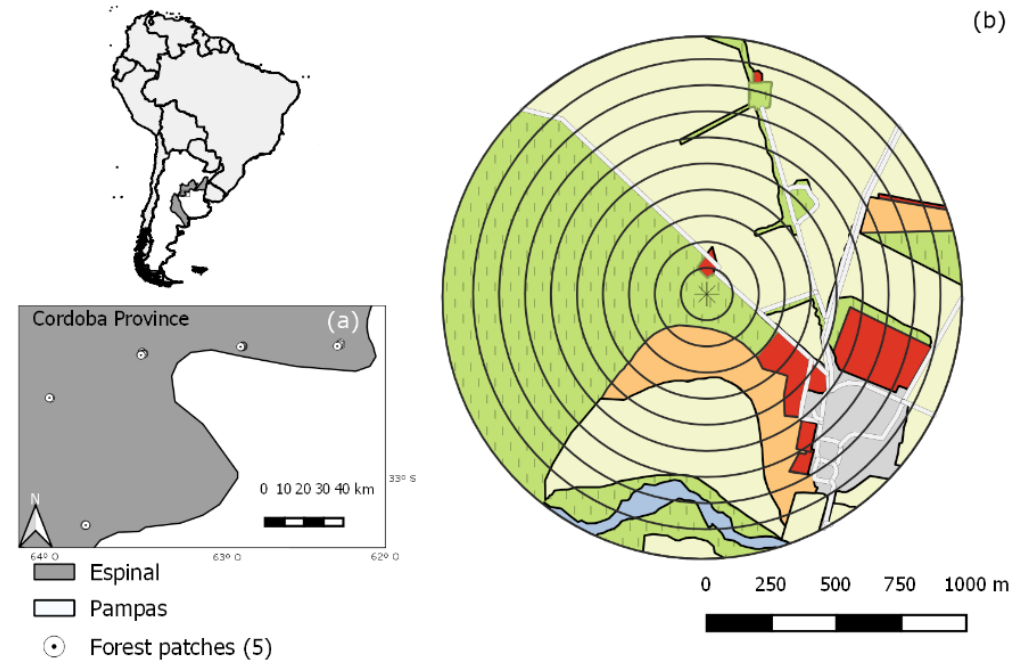

(b)
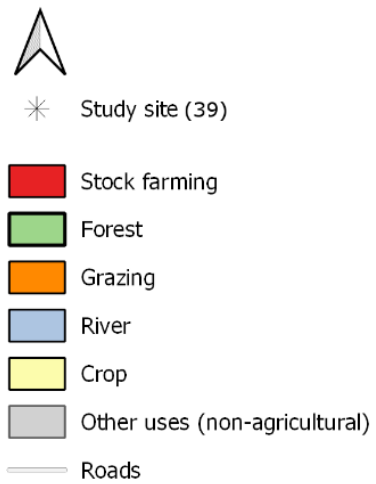

FIGURE I Extent of the Espinal ecoregion in Argentina, (a) location of the forest patches studied, and (b) example of one of the random study sites showing different land use classes and circular bufer areas of $0.1-\mathrm{I}$ km radius (every $100 \mathrm{~m}$ ).

nomenclature was based on (Calvelo and Liberatore, 2002) and Mycobank (2019). Then, the frequency of families and genera was calculated by the summation of the frequency of all species for each site ( 10 trees).

\section{Influence of agricultural land use/land cover area on lichens}

In an agricultural landscape context, land cover refers to the physical cover of land (forests, artificial land, bare land, water areas, etc.) while land use refers to the socioeconomic use that is made of the land (agriculture, livestock farming, residential use, etc.). To integrate both approaches, we used satellite image classification and direct observations made on the ground and, for simplicity, we will refer to land use.

Spatial cover of the different land use types around each forest patch was calculated by means of a visual classification using Google Earth images. The analysis around each forest patches involved 20I5-2016 images and digitized each land use: Espinal forest, crop production, stock farming (cattle, pigs and poultry) and grazing (different grazing management). To avoid multicollinearity problems, the variables "other non-agricultural uses, roads and river" were excluded from the data analysis because they were highly correlated (Spearman's coefficient $>0.7$ ). The classified land uses were restricted to I $\mathrm{km}$ around each patch. Then, in order to evaluate the influence of different land use type on lichen variables we used circular buffer areas of $0.1-1 \mathrm{~km}$ radius (every $100 \mathrm{~m}$ ) around each of the 39 sampling sites.

\section{Statistical analysis}

We used frequency of lichen families and genera as response variable. First, we applied non-parametric correlations (Spearman, $p<0.05$ ) between the land use type at different distances and the frequency of lichen groups. Crustose lichens were not included in this analysis due to difficulties in identifying them at the species level. The distances at which the correlation index had the highest value were selected for each land use type. We assumed that, if the correlation coefficient increases as we enlarge the buffer areas, then the new areas added are still affecting lichen community. When the correlation coefficient becomes lower or similar, we considered that those new added areas were no longer influencing on lichen (Pinho et al., 2008). The area of each land use was log- 10 transformed. Then, the obtained information was used to perform Generalized Mixed Models (GLMM) with the land use variables as a fixed effect, the forest patch as a random factor and the negative binomial error distribution because overdispersion was detected. Analyses were performed using the Infostat software ( $\mathrm{Di}$ Rienzo et al., 2017) with $p<0.05$ as a significance value.

\section{RESULTS}

\section{Lichen diversity and community traits}

Seventy-four epiphytic lichen species were found on the 390 trees surveyed (Table I). The most widely represented genera, in terms of number of species, were Hyperphyscia, Physcia, Heterodermia, and Phaeophyscia (family Physciaceae, which accounts for more than half of the genera reported in this study), followed by Parmotrema. The most frequent species were Crespoa crozalsiana, Xanthoria parietina, Physcia crispa, P. rolfii, Hyperphyscia variabilis and Leptogium cyanescens. Only nine crustose lichens were recorded, but it was not possible to identify all of them to species level. 
Influence of agricultural land use on lichens

We explored correlations between the frequency of Physciaceae, Parmeliaceae, Teloschistaceae, Collemataceae, Verrucariaceae and Ramalinaceae and the agricultural land use at different distances (data not shown). Only the significant correlations for families and genera are shown and in the case of a significant response from a family, all the correlations of their genera are shown (Table 2). The results of GLMM showed that the frequency of Physciaceae increased with increasing cropland area to a distance of $600 \mathrm{~m}$ but it did not show any significant correlations with other land uses (Table 3, Figure 2). Analyzing the contribution of species grouped by genera, one might suspect that Hyperphyscia and Physcia could be the groups that dominate the correlation, since they have the highest frequency values, masking the frequency of other groups. However, it is observed that there are no correlations between these genera, or others of the Physciaceae, and the area occupied by crops (Table 2).

The frequency of Physcia spp. increased with grazing areas, although at a greater distance of influence $(1000 \mathrm{~m})$. By contrast, it was observed that the frequency of Physcia spp. decreased in intensive livestock farming areas $(700 \mathrm{~m})$ (Figure 3 ).

On the other hand, a positive response was observed from the frequency of Collemataceae to the forests area. Although cyanolichens were scarcely represented (only three species) in the sites studied, cyanolichen frequency increased with increasing areas occupied by native forest at an influence distance of $1000 \mathrm{~m}$ (Figure 2). Finally, the frequency of Punctelia spp. seems to decrease at sites with a greater cultivated area, according to the Spearman's coefficient, however the results of GLMM showed that this decreasing is marginally significant.

\section{DISCUSSION}

In this study we evaluated the relationship between different agricultural land use types and the lichen community. This is the first study of an applied neighborhood land cover approach in relation to lichen diversity in Argentina, since until now it has only been used to study other organisms (González et al., 2017a, 2017b). This approach is very useful for optimizing the sampling effort on nearby land uses and allows exploration to find the area of greatest influence on the studied organisms.

Other authors has been applied the neighborhood land cover approach, similarly to our study, showing that air pollution related to urbanization has a strong influence
TABLE I Frequency of lichen species grouped by families (decreasing number of species) and genera at the 39 sites measured (10 trees at each site). $\mathrm{Fol}=$ foliose. Crust $=$ crustose. Squam $=$ squamulose. Frut $=$ fruticulose.

\begin{tabular}{|c|c|c|c|}
\hline Thallus & Family & Species & Freq. \\
\hline Fol & Physciaceae & Hyperphyscia adglutinata & 6.67 \\
\hline Fol & Physciaceae & H. confusa & 0.60 \\
\hline Fol & Physciaceae & H. coralloidea & 6.33 \\
\hline Fol & Physciaceae & H. endochyscea & 2.27 \\
\hline Fol & Physciaceae & H. granulata & 1.00 \\
\hline Fol & Physciaceae & H. minor & 0.30 \\
\hline Fol & Physciaceae & H. pandani & 0.30 \\
\hline Fol & Physciaceae & H. pyrithrocardia & 0.13 \\
\hline Fol & Physciaceae & H. pruinosa & 2.10 \\
\hline Fol & Physciaceae & H. syncolla & 3.85 \\
\hline Fol & Physciaceae & H. tuckermanii & 1.50 \\
\hline Fol & Physciaceae & H. variabilis & 12.95 \\
\hline Fol & Physciaceae & H. viridissima & 0.30 \\
\hline Fol & Physciaceae & Heterodermia albicans & 7.95 \\
\hline Fol & Physciaceae & H. comosa & 0.10 \\
\hline Fol & Physciaceae & H. diademata & 5.54 \\
\hline Fol & Physciaceae & H. obscurata & 0.10 \\
\hline Fol & Physciaceae & H. vulgaris & 0.20 \\
\hline Fol & Physciaceae & Physcia aipolia & 2.12 \\
\hline Fol & Physciaceae & P. atrostriata & 0.83 \\
\hline Fol & Physciaceae & P. caesia & 0.10 \\
\hline Fol & Physciaceae & P. crispa & 16.00 \\
\hline Fol & Physciaceae & P. erumpens & 2.75 \\
\hline Fol & Physciaceae & P. krogiae & 0.20 \\
\hline Fol & Physciaceae & P. poncinsii & 2.20 \\
\hline Fol & Physciaceae & P. rolfii & 11.45 \\
\hline Fol & Physciaceae & P. tribacia & 0.50 \\
\hline Fol & Physciaceae & P. undulata & 4.06 \\
\hline Fol & Physciaceae & Pyxine astridiana & 0.20 \\
\hline Fol & Physciaceae & P. berteriana & 0.20 \\
\hline Fol & Physciaceae & P. cocoës & 2.00 \\
\hline Fol & Physciaceae & P. subcinerea & 1.80 \\
\hline Fol & Physciaceae & Dirinaria applanata & 7.01 \\
\hline Fol & Physciaceae & D. picta & 0.10 \\
\hline Fol & Physciaceae & D. pustulata & 0.10 \\
\hline Fol & Physciaceae & Phaeophyscia hirsuta & 4.00 \\
\hline Fol & Physciaceae & Ph. orbicularis & 0.30 \\
\hline Fol & Physciaceae & Ph. sciastra & 0.30 \\
\hline Fol & Parmeliaceae & Crespoa crozalsiana & 21.87 \\
\hline Fol & Parmeliaceae & C. texana & 0.80 \\
\hline Fol & Parmeliaceae & Myelochroa lindmanii & 6.45 \\
\hline Fol & Parmeliaceae & Parmotrema hababianum & 0.20 \\
\hline Fol & Parmeliaceae & P. muelleri & 3.30 \\
\hline Fol & Parmeliaceae & P. pilosum & 2.01 \\
\hline Fol & Parmeliaceae & P. reticulatum & 2.62 \\
\hline Fol & Parmeliaceae & P. tinctorum & 0.20 \\
\hline Fol & Parmeliaceae & Punctelia hypoleucites & 1.60 \\
\hline Fol & Parmeliaceae & P. borreri & 2.00 \\
\hline Fol & Parmeliaceae & P. punctilla & 1.70 \\
\hline Crust & Teloschistaceae & Caloplaca sp. & 1.24 \\
\hline Frut & Teloschistaceae & Teloschistes cymbalifer & 0.13 \\
\hline Frut & Teloschistaceae & T. chrysophthalmus & 0.40 \\
\hline Fol & Teloschistaceae & Xanthoria parietina & 16.76 \\
\hline Fol & Collemataceae & Collema sp.I & 5.40 \\
\hline Fol & Collemataceae & Collema sp.2 & 0.30 \\
\hline Fol & Collemataceae & Leptogium cyanescens & 9.30 \\
\hline Squam & Verrucariaceae & Catapyrenium exaratum & 3.10 \\
\hline Squam & Verrucariaceae & Endocarpon adscendens & 0.60 \\
\hline Squam & Verrucariaceae & E. pallidulum & 0.30 \\
\hline Squam & Verrucariaceae & Normandina pulchella & 2.20 \\
\hline Squam & Verrucariaceae & Placidium arboreum & 4.40 \\
\hline Crust & Ramalinaceae & Bacidia campalea & 6.85 \\
\hline Frut & Ramalinaceae & Ramalina aspera & 0.50 \\
\hline Frut & Ramalinaceae & R. celastri & 3.44 \\
\hline Frut & Ramalinaceae & R. perisidiosa & 0.10 \\
\hline Frut & Ramalinaceae & R. sorediosa & 0.10 \\
\hline Crust & Candelariaceae & Candelaria concolor & 7.54 \\
\hline Crust & Chrysothricaceae & Chrysothrix candelaris & 2.63 \\
\hline Crust & Graphidaceae & Graphis sp. & 1.40 \\
\hline Crust & Lecideaceae & Lecidea sp. & 2.73 \\
\hline Crust & Stereocaulaceae & Lepraria "brown" & 4.50 \\
\hline Crust & Stereocaulaceae & Lepraria "green" & 9.53 \\
\hline Crust & Stereocaulaceae & Lepraria "white" & 2.40 \\
\hline Crust & Pertusariaceae & Pertusaria sp. & 0.11 \\
\hline
\end{tabular}


TABLE 2 Spearman's correlation coefficient $\rho$ (rho) between land use at different distances of influence and frequency of lichen community (grouped by families and genera). Significance value $\mathrm{p}<0.05$, in bold.

\begin{tabular}{ccccc}
\hline $\begin{array}{c}\text { Land use / Distance of } \\
\text { influence }(\mathrm{m})\end{array}$ & Frequency & $\mathrm{n}$ & $\rho$ & $\mathrm{p}$-value \\
\hline \multirow{5}{*}{ Crop production / 600 } & Physciaceae & 31 & 0.42 & 0.0190 \\
\cline { 2 - 5 } & Dirinaria & 31 & -0.07 & 0.7184 \\
\cline { 2 - 5 } & Heterodermia & 31 & 0.36 & 0.0500 \\
\cline { 2 - 5 } & Hyperphyscia & 31 & 0.18 & 0.3394 \\
\cline { 2 - 5 } & Physcia & 31 & 0.10 & 0.6042 \\
\cline { 2 - 5 } & Pyxine & 31 & 0.18 & 0.3316 \\
\hline Stock farming / 700 & Physcia & 14 & -0.65 & 0.0194 \\
\hline Grazing / 1000 & Physcia & 23 & 0.67 & 0.0004 \\
\hline Crop production / 1000 & Punctelia & 36 & -0.39 & 0.0191 \\
\hline \multirow{2}{*}{ Forest / 1000 } & Collemataceae & 17 & 0.79 & 0.0002 \\
\cline { 2 - 5 } & Collema & 17 & 0.67 & 0.0500 \\
\cline { 2 - 5 } & Leptogium & 17 & 0.45 & 0.0603 \\
\hline
\end{tabular}

TABLE 3 Results from generalized linear mixed models evaluating the effects of different agricultural land uses (at different distances of influence) on lichen frequency grouped by families and genera. The corresponding P-values, slopes and intercepts $( \pm \mathrm{SE})$ are provided. Error distribution used in the model $=$ negative binomial.

\begin{tabular}{|c|c|c|c|c|}
\hline Lichen frequency & $\begin{array}{c}\text { Land use / Distance of } \\
\text { influence }(\mathrm{m})\end{array}$ & $P$ & Slope $( \pm S E)$ & Intercept $( \pm S E)$ \\
\hline \multicolumn{5}{|l|}{ Family level } \\
\hline Physciacea & Crop production / 600 & 0.015 & $0.25 \pm 0.1$ & $2.59 \pm 0.55$ \\
\hline Collemataceae & Native forest / 1000 & 0.035 & $3.47 \pm 1.65$ & $-19.48 \pm 10.14$ \\
\hline \multicolumn{5}{|l|}{ Genus level } \\
\hline Punctelia & Crop production / 1000 & 0.057 & $-1.83 \pm 0.96$ & $\begin{array}{ll}6 & 11.2 \pm 5.74 \\
\end{array}$ \\
\hline \multirow[t]{2}{*}{ Physcia } & Grazing / 1000 & 0.018 & $0.48 \pm 0.21$ & $0.42 \pm 1.12$ \\
\hline & Stock farming / 700 & 0.037 & $-0.57 \pm 0.27$ & $5.41 \pm 1.08$ \\
\hline
\end{tabular}
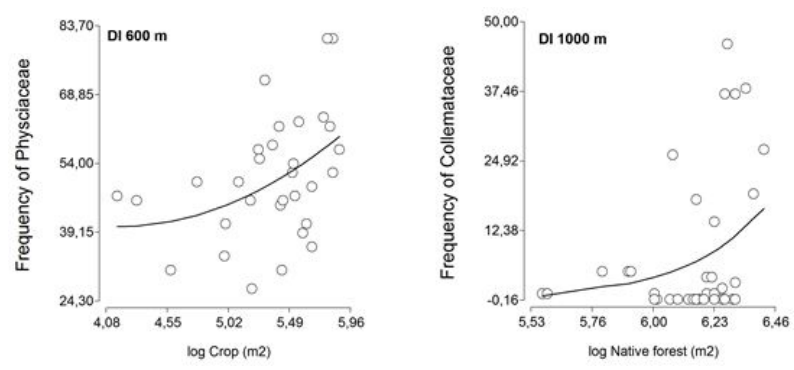

FIGURE 2 Frequency of lichen families Physciaceae (left) and Collemataceae (right) in relation to cropland area and native forest area. $\mathrm{DI}=$ distance of influence. On the $\mathrm{x}$-axes, $\log 10$ transformed area $\left(\mathrm{m}^{2}\right)$.
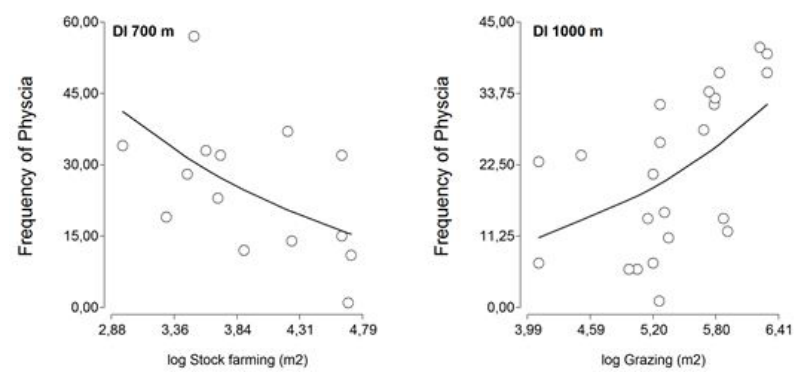

FIGURE 3 Frequency of lichen genus Physcia in relation to livestock according to the intensity of production, with grazing area (left) and stock farming area (right). $\mathrm{DI}=$ distance of influence. On the $\mathrm{x}$-axes, $\log 10$ transformed area $\left(\mathrm{m}^{2}\right)$. on lichen communities, affecting species composition, functional patterns, species richness and photobiont vitality (Koch et al., 2016; Lucheta et al., 2019). Studies in others parts of the world have used this approach in relation to the $\mathrm{N}$-tolerance of lichen species (Munzi et al., 2014; Pinho et al., 2008). However, in our region there is no information about emissions and consequently it is not possible assess the behavior of lichen species.

The maximum correlation between the land use types and the frequency of families and genera of lichens was found between cropland, grazing and stock farming with the foliose Physciaceae and Physcia. In particular, the group of foliose Physciaceae was more frequent in forest patches surrounded by cropland up to $600 \mathrm{~m}$ influence distance and this response is not due to the contribution of a particular genus. This result could be explained for the shared traits between all the species of Physciaceae observed in this work: small and tightly adnate thalli, short and narrow lobes and a similar chemistry. Similarly, Koch et al. (2019) found that these functional traits were indicative of medium/high levels of population density and their associated pollution. In this way, an analysis comparing the frequency of these taxa and their associated functional traits could clarify the response around the increase of Physciaceae related to cropland areas.

In contrast to the result of cropland area, in grazing and stock farming Physcia is the only genus of Physciaceae that responds positively to grazing and negatively to stock farming (feedlots). This result agrees with the general statement that some Physcia species might tolerate atmospheric ammonia from low livestock stocking densities, such as in grazing systems. In support of this, Pinho et al. (20I2) observed a higher number of $\mathrm{N}$-tolerant species (of which many are the same Physcia spp. as in this study) over a low land use intensity gradient. Similar to other studies, it could be that atmospheric ammonia at low concentrations might have a fertilizing effect, increasing the number of $\mathrm{N}$-tolerant lichens (Gaio-Oliveira et al., 200I). On the other hand, we find that sites with a high proportion of livestock farms and other breeding units might have a negative impact on the frequency of Physcia. Taking into account that in agricultural areas a high density of livestock contributes to the increase of $\mathrm{N}$-emissions locally (Beusen et al., 2008), we suggest that, in this study, Physcia could not tolerate emissions from the high stocking density. Although more studies are needed to determine the emissions load at these areas.

In relation to the patches surrounded by forest, only the Collemataceae frequency correlated 
positively. Cyanolichens are known to be the first group that declines when land use intensity is increased in agricultural systems (Aragón et al., 2010) and they were scarcely represented in all the fragments studied. However, the species identified in our study belong to the Leptogium and Collema genera which have Nostoc as the photobiont and it allows tolerance to eutrophication (Hauck, 2010). Additionally, our data suggest that the genera of cyanolichens in this forest are particularly sensitive to local humidity, since they become more frequent at sites protected by higher forest cover.

\section{CONCLUSIONS}

At the present time, the Espinal forest is a mosaic of small forest patches surrounded by crop and livestock production. The lack of measurements of agricultural atmospheric emissions in our region makes it impossible to correlate them with species data. Our results can be used to start a register of species or groups of indicators of impact of agricultural land uses. In this sense, the Physciaceae species identified could have a nitrophytic response in this study area. In particular, Physcia presented a different response to livestock according to the intensity of production, with an increased frequency of these species in the Espinal patches surrounded by grazing but a decreased frequency in areas with livestock farming. This result could indicate an eutrophication process in the Espinal forest, even for Physcia species, although monitoring of emissions is necessary to corroborate this.

\section{REFERENCES}

AGUILLAUME, L; AVILA, A.; PINHO, P., MATOS, P.; LLOP, E.; BRANQUINHO, C. The Critical Levels of Atmospheric Ammonia in a Mediterranean Holm-Oak Forest in North-Eastern Spain. Water, Air, and Soil Pollution, v. 228, n. 3, 2017.

APTROOT, A.; JUNGBLUTH, P.; CÁCERES, M. E. S. A world key to the species of Pyxine with lichexanthone, with a new species from Brazil. Lichenologist, v. 46, n. 5, p. 669-672, 2014.

ARAGÓN, G.; LÓPEZ, R.; MARTÍNEZ, I. Effects of Mediterranean dehesa management on epiphytic lichens. Science of the Total Environment, v. 409, n. I, p. II6- 122, 2010.

BELINCHON, R.; MARTINEZ, I.; ESCUDERO, A.; ARAGÓN, G.; VALLADARES, F. Edge effects on epiphytic communities in a Mediterranean Quercus pyrenaica forest. Journal of Vegetation Science, v. I8, n. I, p. 8I-90, 2007.

BEUSEN, A. H. W.; BOUWMAN A.F.; HEUBERGER P. S. C.; VAN DRECHT G.; VAN DER HOEK K. W. Bottom-up uncertainty estimates of global ammonia emissions from global agricultural production systems. Atmospheric Environment, v. 42, n. 24, p. 6067-6077, 2008.
BLUM, W. E. H. Soil and land resources for agricultural production: general trends and future scenarios-a worldwide perspective. International Soil and Water Conservation Research, v. I, n. 3, p. I-14, 2013.

BOLTERSDORF, S. H.; WERNER, W. Lichens as a useful mapping tool? an approach to assess atmospheric $\mathrm{N}$ loads in Germany by total $\mathrm{N}$ content and stable isotope signature. Environmental monitoring and assessment, v. I86, n. 8, p. 4767-78, 2014.

BOUDREAULT, C.; BERGERON, Y.; DRAPEAU, P.; MASCARUA LOPEZ, L. Edge effects on epiphytic lichens in remnant stands of managed landscapes in the eastern boreal forest of Canada. Forest Ecology and Management, v. 255, n. 5-6, p. |46I-I47I, 2008.

CABIDO, M.; ZEBALLOS, S. R.; ZAK, M.; CARRANZA, M. Native woody vegetation in central Argentina: Classification of Chaco and Espinal forests. Applied Vegetation Science, v. 21 , n. 2, p. 298-3II, 2018

CALVELO, S.; LIBERATORE, S. Catálogo de los líquenes de la Argentina. Kurtziana, v. 29, n. 2, p. 7-170, 2002.

ELIX, J. A. A catalogue of standardized chromatographic data and biosynthetic relationships for lichen substances. Third Edition. Published by the author, Canberra (Australia), n. September, p. I-323, 2014.

ESTRABOU, C.; RODRÍGUEZ, J. M.; PRIERI, B.; LIJTEROFF, R. Contribución al conocimiento de los macrolíquenes del extremo Sur del Gran Chaco (Argentina). Kurtziana, v. 32, n. I, p. 25-43, 2006

ESTRABOU, C.; FILIPPINI, E.; SORIA, J. P.; SCHELOTTO, G.; RODRIGUEZ, J. M. Air quality monitoring system using lichens as bioindicators in Central Argentina. Environmental Monitoring and Assessment, v. I82, n. I-4, p. 375-383, 20 II.

ESTRABOU, C.; QUIROGA, C.; RODRÍGUEZ, J. M. Lichen community diversity on a remnant forest in south of Chaco region (Cordoba, Argentina). Bosque (Valdivia), v. 35, n. I, p. $49-55,2014$

FAO. Livestock's long shadow - environmental issues and options. Food and Agriculture Organization of the United Nations, v. 3, n. I, p. I-377, 2006.

FILIPPINI, E.; QUIROGA, G., RODRIGUEZ, J. M.; ESTRABOU, C. The genus Hyperphyscia (Physciaceae, Ascomycota) in Argentina. Sydowia, v. 67, 2015.

FILIPPINI, E. R.; RODRIGUEZ, J. M.; ESTRABOU, C. Lichen community from an endangered forest under different management practices in central Argentina. LAZAROA, v. 35 , p. 55-63, 2014.

FRATI, L.; SANTONI, S.; NICOLARDI, V.; GAGGI, C.; BRUNIALTI, G.; GUTTOVA, A.; GAUDINO, S.; PATI, A.; PIRINTSOS, S. A.; LOPPI, S. Lichen biomonitoring of ammonia emission and nitrogen deposition around a pig stockfarm. Environmental Pollution, v. I46, n. 2, p. 3 II316, 2007. 
FRATI, L.; BRUNIALTI, G.; LOPPI, S. Effects of reduced nitrogen compounds on epiphytic lichen communities in Mediterranean Italy. Science of the Total Environment, v. 407, n. I, p. 630-637, 2008.

GALLOWAY, J. N.; ABER, J. D.; ERISMAN, J. W.; SEITZINGER, S. P.; HOWARTH, R. W.; COWLING, E. B.; COSBY, B. J. The Nitrogen Cascade. BioScience, v. 53, n. 4, p. 34I, 2003.

GEISER, L. H.; JOVAN, S. E.; GLAVICH, D. A.; PORTER, M. $K$. Lichen-based critical loads for atmospheric nitrogen deposition in Western Oregon and Washington Forests, USA. Environmental Pollution, v. 158, n. 7, p. 24I2242I, 2010.

GONZÁLEZ, E.; SALVO, A.; VALLADARES, G. Natural vegetation cover in the landscape and edge effects: differential responses of insect orders in a fragmented forest. Insect Science, v. 24, n. 5, p. 89I-90I, 2017 a.

GONZÁLEZ, E.; SALVO, A.; VALLADARES, G. Arthropod communities and biological control in soybean fields: Forest cover at landscape scale is more influential than forest proximity. Agriculture, Ecosystems and Environment, v. 239, p. 359-367, 20I7b.

GUIDA JOHNSON, B.; ZULETA, G. A. Land-use land-cover change and ecosystem loss in the Espinal ecoregion, Argentina. Agriculture, Ecosystems and Environment, v. I8I, p. $31-40,2013$.

HAUCK, M. Ammonium and nitrate tolerance in lichens. Environmental pollution (Barking, Essex: 1987), v. I58, n. 5, p. II27-33, 2010.

JENNINGS, S. B.; BROWN, N. D.; SHEIL, D. Assessing forest canopies and understorey illumination: canopy closure, canopy cover and other measures. Forestry, v. 72, n. I, p. 59-74, 1999.

JUNGBLUTH, P.; MARCELLI, M. P.; KALB, K. A new species and a new record of Pyxine (Physciaceae) with norstictic acid from São Paulo State, Brazil. Mycotaxon, v. I I 5, n. I, p. $435-442,201$ I.

$\mathrm{KOCH}, \mathrm{N}$. M.; BRANQUINHO, C.; MATOS, P.; PINHO, P.; LUCHETA, F; MARTINS, S. M. A.; VARGAS, V. M. F. The application of lichens as ecological surrogates of air pollution in the subtropics: a case study in South Brazil. Environmental Science and Pollution Research, 2016.

$\mathrm{KOCH}$, N. M.; MATOS, P.; BRANQUINHO, C.; PINHO, P.; LUCHETA, F; MARTINS, S. M. A.; VARGAS, V. M. F. Selecting lichen functional traits as ecological indicators of the effects of urban environment. Science of the Total Environment, v. 654, p. 705-7I3, 2019.

KRUPA, S. V. Effects of atmospheric ammonia $\left(\mathrm{NH}_{3}\right)$ on terrestrial vegetation: a review. Environmental Pollution, v. I24, n. 2, p. I79-22।, 2003.
LEWIS, J. P.; NOETINGER, S.; PRADO, D. E.; BARBERIS, I. $M$. Woody vegetation structure and composition of the last relicts of Espinal vegetation in subtropical Argentina. Biodiversity and Conservation, v. 18, n. 13, p. 36153628, 2009

LUCHETA, F; MOSSMANN, N.; ISABEL, M.; PLANGG, R. Lichens as indicators of environmental quality in southern Brazil: An integrative approach based on community composition and functional parameters. Ecological Indicators, v. 107, n. July, p. I05587, 2019.

MCMURRAY, J. A.; ROBERTS, D. W.; GEISER, L. H. Epiphytic lichen indication of nitrogen deposition and climate in the northern rocky mountains, USA. Ecological Indicators, v. 49, p. |54-|6|, $20 \mid 5$.

MUNZI, S.; CORREIA, O.; SILVA, P.; LOPES, N.; FREITAS, C.; BRANQUINHO, C.; PINHO, P. Lichens as ecological indicators in urban areas: Beyond the effects of pollutants. Journal of Applied Ecology, v. 5I, n. 6, p. I750- I757, 2014.

PAOLI, L.; PIRINTSOS, S. A.; KOTZABASIS, K.; PISANI, T.; NAVAKOUDIS, E.; LOPPI, S. Effects of ammonia from livestock farming on lichen photosynthesis. Environmental Pollution, v. I58, n. 6, p. 2258-2265, 2010.

PINHO, P.; AUGUSTO, S.; MAGUAS, C.; PEREIRA, M. J.; SOARES, A.; BRANQUINHO, C. Impact of neighbourhood land-cover in epiphytic lichen diversity: Analysis of multiple factors working at different spatial scales. Environmental Pollution, v. I5I, n. 2, p. 4I4-422, 2008.

PINHO, P.; BRANQUINHO, C.; CRUZ, C.; TANG, Y. S.; DIAS, T.; ROSA, A. P.; MÁGUAS, C.; MARTINS-LOUÇÃO, M. A.; SUTTON, M. A. Assessment of critical levels of atmospheric ammonia for lichen diversity in cork-oak woodland, Portugal. In: Atmospheric ammonia: detecting emission changes and environmental impacts, 2009, p. 109-119.

PINHO, P.; BERGAMINI, A., CARVALHO, P.; BRANQUINHO, C.; STOFER, S.; SCHEIDEGGER, C.; MÁGUAS, C. Lichen functional groups as ecological indicators of the effects of land-use in Mediterranean ecosystems. Ecological Indicators, v. I5, n. I, p. 36-42, 2012.

QUIROGA, G.; ESTRABOU, C.; RODRIGUEZ, J. M. Lichen community response to different management situations in Cerro Colorado protected forest (Cordoba, Argentina). LAZAROA, v. 29, p. |3|-|38, 2008.

RODRIGUEZ, J. M.; ESTRABOU, C.; FENOGLIO, R., ROBBIATI, F.; SALAS, M. C.; QUIROG̈A, G. Recuperación post-fuego de la comunidad de líquenes epífitos en la provincia de Córdoba, Argentina. Acta Botanica Brasilica, v. 23, n. 3, p. 854-859, 2009.

VIGLIZZO, E. F.; FRANK, F. C.; CARREÑO, L. V.; JOBBÁGY, E. G.; PEREYRA, H.; CLATT, J.; PINCÉN, D.; RICARD, M. Ecological and environmental footprint of 50 years of agricultural expansion in Argentina. Global Change Biology, v. I7, n. 2, p. 959-973, 2011 .

ZEBALLOS, S. R.; GIORGIS, M. A.; CABIDO, M. R.; ACOSTA, A. T. R., IGLESIAS, R.; CANTERO, J. J. The lowland seasonally dry subtropical forests in central Argentina: vegetation types and a call for conservation. Veg. Classif. Surv, V. I, p. 87-102, 2020. 